\title{
RHEOLOGICAL BEHAVIOR OF WATER-IN-OIL EMULSIONS OF HEAVY AND EXTRA-HEAVY LIVE OILS: EXPERIMENTAL EVALUATION
}

\author{
COMPORTAMIENTO REOLÓGICO DE EMULSIONES AGUA EN ACEITE PARA \\ ACEITES VIVOS PESADOS Y EXTRA-PESADOS: EVALUACIÓN EXPERIMENTAL
}

Libia-Sofia Sandoval-Rodríguez'; Wilson A. Cañas-Marín²* and Ramiro Martínez-Rey ${ }^{1}$

'Escuela de Ingeniería Química, Universidad Industrial de Santander, Bucaramanga, Colombia ${ }^{2}$ Ecopetrol S.A. - Instituto Colombiano del Petróleo (ICP), A.A. 4185 Bucaramanga, Colombia

e-mail:wilson.cmarin@ecopetrol.com.co

(Received: Jan. 31, 2014; Accepted: May 20, 2014)

\begin{abstract}
table emulsions were prepared with heavy and extra-heavy live oils by using a set-up recently built at Ecopetrol S.A. - Instituto Colombiano del Petróleo (ICP). This equipment permits to prepare waterin-oil emulsions at reservoir conditions without any change on the overall hydrocarbon composition. The live emulsions were prepared with water contents up to $26 \%$ in volume. Then, a capillary viscometer was used to study the rheological behavior of these emulsions at different shear rates and pressures up to 24.2 MPa. The experimental results permit to conclude that the prepared and evaluated emulsions have a Newtonian behavior for the conditions of water contents, shear rates, pressures and temperature $\left(60^{\circ} \mathrm{C}\right)$ here studied. For these emulsions, a logarithmic behavior of the viscosity with respect to pressure and water content was also observed.
\end{abstract}

Keywords: Live emulsions, Rheology of emulsions, Heavy live oil, Capillary viscometer, Petroleum reservoir.

How to cite: Sandoval-Rodríguez, L. S., Cañas-Marín, W. A. \& Martínez-Rey, R. (2014). Rheological behavior of water-inoil emulsions of heavy and extra-heavy live oils: experimental evaluation. CT\&F - Ciencia, Tecnología y Futuro, 5(4), 5-24.

*To whom correspondence should be addressed 


\section{RESUMEN}

P prepararon emulsiones estables de aceites vivos pesados y extra-pesados usando un equipo desarrollado recientemente en Ecopetrol S.A. - Instituto Colombiano del Petróleo (ICP). Este equipo permite preparar emulsiones agua-en-aceite a condiciones de yacimiento sin afectar la composición global del hidrocarburo. Las emulsiones de fluidos vivos fueron preparadas con cortes de agua hasta de $26 \%$ en volumen. Entonces, se usó un viscosímetro capilar para estudiar el comportamiento reológico de las emulsiones a diferentes velocidades de deformación y presiones hasta de 24.2 MPa. Los resultados experimentales permiten concluir que las emulsiones preparadas y evaluadas tienen un comportamiento Newtoniano para las condiciones de cortes de agua, tasas de deformación, presiones y temperatura $\left(60^{\circ} \mathrm{C}\right)$ aquí estudiadas. Para estas emulsiones, también se observó un comportamiento logarítmico de la viscosidad con respecto a la presión y al contenido de agua.

Palabras clave: Emulsiones, Reología, Aceites vivos pesados, Viscosímetro capilar, Yacimiento de petróleo.

\section{RESUMO}

F ram preparadas emulsões estáveis de óleos vivos pesados e extra pesados usando um equipamento desenvolvido recentemente na Ecopetrol S.A. - Instituto Colombiano del Petróleo (ICP). Este equipamento permite preparar emulsões água em óleo a condições de jazidas sem afetar a composição global do hidrocarboneto. As emulsões de fluídos vivos foram preparadas com cortes de água de até $26 \%$ em volume. Então, foi usado um viscosímetro capilar para estudar o comportamento reológico das emulsões a diferentes velocidades de deformação e pressões de até $24.2 \mathrm{MPa}$. Os resultados experimentais permitem concluir que as emulsões preparadas e avaliadas têm um comportamento Newtoniano para as condições de cortes de água, taxas de deformação, pressões e temperatura $\left(60^{\circ} \mathrm{C}\right)$ aqui estudadas. Para estas emulsões, também foi observado um comportamento logarítmico da viscosidade com relação à pressão e ao conteúdo de água.

Palavras-chave: Emulsões, Reologia, Óleos vivos pesados, Viscosímetro capilar, Jazida de petróleo. 


\section{INTRODUCTION}

Two third parts of the worldwide crude oils are produced in an emulsified way; these emulsions are mainly of the water-in-oil type due to the production processes. Dehydration of petroleum reservoir downhole samples is necessary to determine reliable PVT (Pressure, Volume, Temperature) properties for the analysis of the fluid behavior (Memon et al., 2010) and to carry out an efficient management of hydrocarbon reservoirs (Nagarajan, Honarpour \& Sampath, 2007). Particularly for heavy and extra-heavy fluids, this dehydration process is commonly very difficult and complex because the formed emulsions are usually very stable. In addition, the most known dehydration techniques are only applicable at atmospheric conditions (Memon et al., 2010), which is prohibited to down-hole samples (live oils), because these have been captured at high pressure and high temperature, and therefore need to be analyzed under those conditions.

Over the last 40 years, many studies have been carried out for trying to understand these complex emulsions. However, there are still many outstanding questions about, for example, their behavior (André, 2009). This complexity is related to the composition of the natural surfactant molecules in the crude oil, which include a great range of chemical structures and molecular weights (Langevin, Poteau, Hénaut \& Argillier, 2004). The rheology of live oil emulsions is precisely an understudied topic, mainly at high pressures (Johnsen \& Rønningsen, 2003; Alboudwarej et al., 2007).

In the present work, rheological measurements of water-in-live oil emulsions prepared in an in-house equipment were carried out. For this purpose, two live heavy crude oils and one live extra-heavy crude oil, which have bubble points above $3.3 \mathrm{MPa}$, were used. The rheology was studied in a capillary viscometer at $60^{\circ} \mathrm{C}$, different shear rates, water cuts up to $26 \%$ in volume, and pressures as high as $24.2 \mathrm{MPa}$.

\section{THEORETICAL BACKGROUND}

The viscosity is an essential property in the petroleum industry to understand, for example, the mobility of the hydrocarbons from the reservoir to surface facilities. Ideally, it should be measured in a PVT laboratory using representative reservoir mixtures. Unfortunately, due to activities of drilling, sampling, chemical treatments, production, etc., these hydrocarbon samples are commonly captured in form of water-in-oil emulsions before the respective inversion point is reached. In this kind of emulsions, the droplets of the dispersed phase (water) have deformable interfaces of different types and the interactions between them play an important role on the rheology of the emulsions. It is very difficult to try to explain how the interfaces of the droplets are deformed (Princen, Aronson \& Moser, 1980). In addition, the presence of the interfaces modifies the flow patterns within the fluid, thus increasing the energy dissipation and causing a change in the viscosity. How this occurs depends on the nature of the hydrodynamic flow at the interfaces (Mason, Bibette \& Weitz, 1996). Due to all above, the viscosities of water-in-oil emulsions are substantially higher than the viscosity of the corresponding dehydrated hydrocarbon (Pal \& Rhodes, 1985; Pal \& Rhodes, 1989; Johnsen \& Rønningsen, 2003).

The viscosity of a water-in-oil emulsion depends on, among other variables, the viscosity of the continuous phase (i.e., oil), the volumetric fraction of the dispersed phase $(\phi)$-i.e., water, the shear rate (for Non Newtonian emulsions) and the temperature. Of the variables above, the temperature and the volume fraction of water $(\phi)$ are maybe the most influential ones (Pal \& Rhodes, 1989; Johnsen \& Rønningsen, 2003). However, it is well known that the behavior of the viscosity of an emulsion is also influenced by the packing of the droplets of the dispersed phase (Mason et al., 1996) and the drop size distribution of the disperse phase (water droplets). Pal (2000) studied several oil/water emulsions by using a controlled-stress rheometer and found that at low-to-moderate values of water cut, the emulsions could exhibit Newtonian behavior. However, at higher values of water cuts, emulsions exhibited shear-thinning behavior strongly influenced by the droplet size; a significant increase in the viscosity occurs when the droplet size is reduced. That author found also that the droplet size does not exert any influence on the viscosity of Newtonian emulsions. For water/oil emulsions, Abivin et al. (2009) found that the viscosity versus shear rate curves exhibited a Newtonian behavior 
for low shear rates (below $100 \mathrm{~s}^{-1}$ ). The Newtonian viscosity increased as the water cut increased (naturally, the droplet size distributions are different for each water cut, affecting the emulsion viscosity). Whatever the emulsion, viscosity decreased for shear rates higher than $100 \mathrm{~s}^{-1}$, and showed a shear thinning tendency (Non Newtonian behavior - see Figure 11 in that reference). This shear thinning behavior at higher shear has been explained by changes in the droplet geometry from spherical (Newtonian emulsion) to stretched droplets of elliptical cross sections (Abivin et al., 2009; Thompson, Pearson \& Mackley, 2001).

For petroleum reservoir fluids (live fluids), the pressure also plays a key role on the viscosity due to the changes in pressure that the fluid inevitably suffers from the reservoir up to surface. Despite the importance of this variable, its influence on mechanical properties has been less studied in comparison to the temperature (Martín-Alfonso et al., 2007). In fact, reports of experimental measurements of viscosities for emulsions under pressure have been very scarce in the literature and the data reported usually do not exceed $10 \mathrm{MPa}$ (Johnsen \& Rønningsen, 2003; Kokal \& Álvarez, 2003; Albou-dwarej et al., 2007; Memon et al., 2010).

The measurement of the apparent viscosity of an emulsified sample is not a trivial problem because of factors that could affect the results, such as the differences inside the sample itself (heterogeneity), stability problems, variation in drop size distribution and the transient nature of the emulsion (Kokal \& Álvarez, 2003). Several methodologies and equipment such as electromagnetic, capillary, and falling ball viscometers, parallel plate rheometers, etc, are available to experimentally determine the viscosity of emulsions. However, the capillary viscometer is probably the most used instrument for measuring the viscosity as a function of the shear rate for a wide range of materials
(Munoz \& Yeow, 1996), and therefore could be used for heavy oil viscosity measurements at temperatures and pressures above atmospheric conditions. In addition, it is recommended for viscosity measurements of emulsions because the fluid dynamics is less affected by the relatively low concentration of contaminant fine particle (Memon et al., 2010). This type of viscometer has been used to measure different types of emulsions at low or medium pressures (Memon et al., 2010; Alboudwarej et al., 2007; Alvarado \& Marsden, 1979; Muller, Lessnig, Platz \& Koepke, 1966; Albers \& Overbeek, 1960).

\section{EXPERIMENTAL DEVELOPMENT}

\section{Fluids Used}

Synthetic brine with an equivalent salinity of 6200 $\mathrm{mg} / \mathrm{L}$ of sodium and a neutral $\mathrm{pH}$ was used to prepare the emulsions. As continuous phase, two heavy crude oils and one extra-heavy crude oil were chosen; these fluids were prepared by a recombination procedure during several days. The recombined samples were conditioned at high pressure and at a temperature of $60^{\circ} \mathrm{C}$, and then analyzed to determine their compositions and physical properties. The physical properties were determined as follow: The water content was measured by using the "water by distillation" technique (ASTM D400611); API gravity was measured using an Anton Paar densimeter; and Gas-Oil Ratio (GOR) was determined in a Gasometer brand DBR. The asphaltene content was established by separation of the fraction with n-heptane and a subsequent process of refluxing and repose under darkness conditions to achieve the precipitation and avoid the sample oxidation (IP Test Method 143).

The summary of the properties of these recombined samples are shown in Table 1, and, as can be seen, the Fluid $\mathrm{C}$ is the only base fluid completely dehydrated.

Table 1. Properties of the hydrocarbon fluids used in the experiments.

\begin{tabular}{|ccccc|}
\hline Fluid & $\begin{array}{c}\text { Initial Water } \\
\text { Content }(\% \text { Wt) }\end{array}$ & $\begin{array}{c}\text { API } \\
\text { Gravity }\end{array}$ & $\begin{array}{c}\text { GOR (SCF/STB) } \\
\text { (Gas-Oil Ratio) }\end{array}$ & $\begin{array}{c}\text { Asphaltene } \\
\text { Content (\% Wt) }\end{array}$ \\
\hline C & 0 & 14.1 & 35.4 & 11.57 \\
\hline E & 1.83 & 15.9 & 134.6 & 6.73 \\
\hline F & 2.3 & 8.5 & 68.3 & 15.04 \\
\hline
\end{tabular}


The overall compositions of the recombined fluids are shown in Table 2. These compositions were determined by the gas chromatography technique (GPA 2286-95, ASTM D5307-07). In this Table the composition corresponds to molar percentage which was calculated using the molecular weight distribution of Katz and Firoozabadi (1978).

Table 2. Overall compositions (\% molar) of synthetic live fluids used in this work.

\begin{tabular}{|cccc|}
\hline Component & $\begin{array}{c}\text { Fluid } \mathrm{C} \\
\text { (\% molar) }\end{array}$ & $\begin{array}{c}\text { Fluid } \mathrm{E} \\
\text { (\% molar) }\end{array}$ & $\begin{array}{c}\text { Fluid } \mathrm{F} \\
\text { (\% molar) }\end{array}$ \\
\hline $\mathrm{N}_{2}$ & 0.0045 & 0.0060 & 0.0000 \\
\hline $\mathrm{CO}_{2}$ & 0.0016 & 0.0045 & 0.0000 \\
\hline $\mathrm{C}_{1}$ & 9.3724 & 25.5772 & 18.2149 \\
\hline $\mathrm{C}_{2}$ & 0.1213 & 0.3743 & 0.3486 \\
\hline $\mathrm{C}_{3}$ & 0.1371 & 0.3945 & 0.4602 \\
\hline $\mathrm{i}-\mathrm{C}_{4}$ & 0.0502 & 0.2185 & 0.2582 \\
\hline $\mathrm{C}_{4}$ & 0.0881 & 0.2556 & 0.4759 \\
\hline $\mathrm{i}-\mathrm{C}_{5}$ & 0.0475 & 0.3920 & 0.3946 \\
\hline $\mathrm{C}_{5}$ & 0.0653 & 0.1459 & 0.3494 \\
\hline $\mathrm{C}_{6}$ & 0.0452 & 0.5758 & 0.5161 \\
\hline $\mathrm{C}_{7}$ & 0.0305 & 1.8499 & 0.7718 \\
\hline $\mathrm{C}_{8}$ & 0.0191 & 2.9113 & 0.7075 \\
\hline $\mathrm{C}_{9}$ & 0.0744 & 3.0623 & 0.8448 \\
\hline $\mathrm{C}_{10}$ & 0.2463 & 3.2109 & 0.7558 \\
\hline $\mathrm{C}_{11}$ & 0.7717 & 2.6968 & 0.8220 \\
\hline $\mathrm{C}_{12}$ & 1.6008 & 2.5610 & 1.1047 \\
\hline $\mathrm{C}_{13}$ & 2.8108 & 2.9232 & 1.6763 \\
\hline $\mathrm{C}_{14}$ & 3.3637 & 2.4705 & 1.7065 \\
\hline $\mathrm{C}_{15}$ & 4.1164 & 2.5748 & 2.0270 \\
\hline $\mathrm{C}_{16}$ & 3.4594 & 2.1757 & 2.0258 \\
\hline $\mathrm{C}_{17}$ & 4.0545 & 2.1117 & 2.1241 \\
\hline $\mathrm{C}_{18}$ & 4.3209 & 2.0411 & 2.2052 \\
\hline $\mathrm{C}_{19}$ & 4.2406 & 2.0139 & 2.2443 \\
\hline $\mathrm{C}_{20}$ & 4.3723 & 1.8376 & 2.2471 \\
\hline $\mathrm{C}_{21}$ & 3.5586 & 1.6024 & 2.1123 \\
\hline $\mathrm{C}_{22}$ & 3.4788 & 1.5417 & 1.9630 \\
\hline $\mathrm{C}_{23}$ & 3.3422 & 1.4548 & 1.9153 \\
\hline $\mathrm{C}_{24}$ & 2.8035 & 1.2582 & 1.8704 \\
\hline $\mathrm{C}_{25}$ & 2.5535 & 1.1941 & 1.6780 \\
\hline $\mathrm{C}_{26}$ & 2.4951 & 1.1552 & 1.4829 \\
\hline $\mathrm{C}_{27}$ & 2.3340 & 1.1337 & 1.5344 \\
\hline $\mathrm{C}_{28}$ & 2.2647 & 1.0493 & 1.4380 \\
\hline $\mathrm{C}_{29}$ & 2.1742 & 1.0359 & 1.4004 \\
\hline $\mathrm{C}_{30+}$ & 31.5809 & 25.9899 & 42.1161 \\
\hline Benzene $_{\text {Toluene }}$ & 0.0000 & 0.0297 & 0.0388 \\
\hline & 0.0000 & 0.1699 & 0.1697 \\
\hline & & & \\
\hline & & \\
\hline
\end{tabular}

\section{Equipment}

The emulsions were prepared by using an inhouse equipment recently developed at the ICP. At present, this setup is under patentability study, and therefore details about its configuration or operating procedure are omitted in this paper. This equipment permits to prepare stable water-in-oil emulsions for live oils without any effect on the hydrocarbon overall composition. After being prepared, the emulsions were stored in pressurized cylinders. Also, an optical microscope brand OLYMPUS BX $53^{\circledR}$ was used to determine the type of emulsion; while the emulsified water drop size distribution was analyzed in a Mastersizer equipment from Malvern Instruments. This last device has been extensively used for determining the drop size at atmospheric pressure; its operating principle is based on measuring the intensity of the transmitted light through the sample, because the emulsions disperse the light originally generated by a laser (Binks et al., 1999; Forgiarini, Esquena, González \& Solans, 2000; Lethuaut, Métro \& Genot, 2002; Pays et al., 2002; Malkin, Masalova, Slatter \& Wilson, 2004; Moradi, Alvarado \& Huzurbazar, 2010). This information permits to calculate the emulsion drop size distribution based on the dispersion patterns. Previous to the measurement in the Mastersizer equipment, the emulsions were diluted with Varsol for obtaining reliable data, because the heavy oils have a high degree of light absorbance.

Finally, for all types of sample (i.e., crudes and emulsions) the viscosities were measured at high pressure in an in-house capillary viscometer also built at the $I C P$. The capillary viscometer consists of two high-pressure cylinders connected by a capillary coil of well-known dimensions (diameter: $1.4328 \mathrm{~mm}$ and length: $2.933 \mathrm{~m}$ ). A calibrated transducer of differential pressure is used to monitor the pressure drop across the capillary coil at different volumetric flow rates (shear rates). The capillary viscometer is based on the fully developed laminar flow theory (Hagen-Poiseuille). From this theory, the shear rate, shear stress and viscosity are expressed in terms of flow rates, pressure drops and geometry as follow:

$\tau_{w}=\left(\frac{\Delta P}{L}\right)\left(\frac{D}{4}\right)$ 
$\dot{\gamma}_{w}=\left(\frac{(3 n+1)}{4 n}\right)\left(\frac{8 Q}{\pi D^{3}}\right)$

$\eta=\frac{\tau_{w}}{\dot{\gamma}_{w}}=\left(\frac{4 n}{3 n+1}\right)\left(\frac{\pi D^{4}}{128 L} \frac{\Delta P}{Q}\right)$

Where:

$\tau_{w}$ is the shear stress, $\dot{\gamma}_{w}$ is the shear rate at the wall, $\triangle P$ is the pressure drop through the capillary viscometer, $\mathrm{L}$ is the length of the capillary coil, $\mathrm{D}$ is the diameter of the capillary coil, Q is the flow rate, $\eta$ is the viscosity, and $\mathrm{n}$ is the slope of the measured $\log \left(\tau_{w}\right)-\log \left(\dot{\gamma}_{w}\right)$ curve, and represents the Newtonian $(\mathrm{n}=1)$ or NonNewtonian $(n \neq 1)$ characteristic of the fluid. Obviously, for Newtonian fluids (n=1) Equation 3 is reduced to the well-known Hagen-Poiseuille expression:

$\eta=\frac{\tau_{w}}{\dot{\gamma}_{w}}=\left(\frac{\pi D^{4}}{128 L} \frac{\Delta P}{Q}\right)$

In other words, Equations 1-3 are valid also for Non-Newtonian fluids in laminar flow. For this reason the capillary viscometer has been broadly used in the oil industry (Liauh \& Liu, 1984; Haney, 1985; Kobayashi, Yoshida \& Kurano, 1991; Barrufet \& Setiadarma, 2003). Capillary viscometer has been also used successfully in the measurement of viscosity of complex fluids such as foams (Wenzel, Stelson \& Brungraber, 1967; David \& Marsden, 1969). One of the advantages of the capillary viscometer is the ability to achieve very high shear rates, even with high viscosity samples. The main disadvantages of this kind of viscometers are high residence time and variation of shear across the flow, which can change the internal structure of complex test fluids, and a shear heating with very high-viscosity samples could be also possible (Webster \& Eren, 2014). However, the capillary viscometer is the most common approach to obtaining the shear rate dependency for live oils under both high pressure and high temperature conditions, when rotational rheometers cannot be used.

The validation of the capillary viscometer was carried out by using water type 1 and n-decane of pure grade (Barrufet \& Setiadarma, 2003); the viscosities measured were then compared with data from NIST, giving percentages of error less than $1 \%$.

\section{RESULTS AND DISCUSSION}

\section{Emulsions Characterization}

The prepared emulsions were stable before, during and even after all experiments were finished. As a rule, no emulsion exhibited any free water even after four weeks of being prepared.

In order to determine both the emulsified water drop size distribution and the type of emulsion, a subsample of the respective emulsion was controllably flashed from pressurized conditions to ambient temperature and atmospheric pressure. The above process was realized by the isobaric drainage from the high pressure source, through a valve which allows the controlled flow of the subsample to be analyzed.

Then, by using the microscope above described, it was possible to conclude that all the obtained emulsions were water-in-oil (W/O), as depicted in Figures 1a, 1b and $1 \mathrm{c}$.

Even though the effect of the water drop size on the viscosity of the fluids was not the objective of the present study, and the results were not analyzed systematically, some of these are briefly discussed due to the importance of the droplet size on the control of the flocculation (drop diffusion into a continuous phase), coalescence, resistance to sedimentation or creaming, and the rheology (Moradi et al., 2010). However, it is important to understand that the droplet size does not exert any influence on the viscosity of Newtonian emulsions at the same water cut and low-to-moderate shear rates, provided the droplet deformation is incipient (Abivin et al., 2009; Pal, 2000).

Figures $2 \mathrm{a}, 2 \mathrm{~b}$ and $2 \mathrm{c}$ depict the frequency distribution and the cumulative volume of the droplet size for each one of the prepared emulsions. As shown, most of these emulsions exhibit normal distributions, except the emulsion with the smallest water content $(\phi=0.11)$ for Fluid C, and the emulsion with the highest water content $(\phi=0.26)$ for Fluid F. Figure 3 shows the drop size distributions for each one of the prepared emulsions. These distributions are represented as the drop size variation against the accumulated volume percentage of the sample analyzed. 


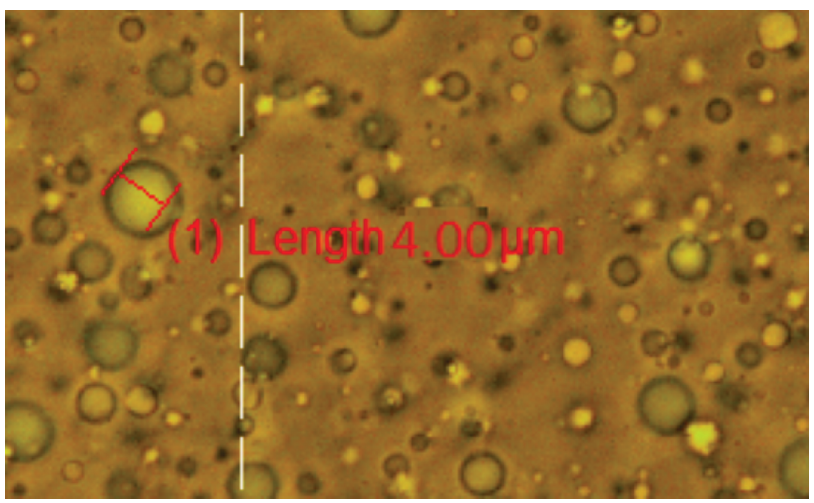

(a)

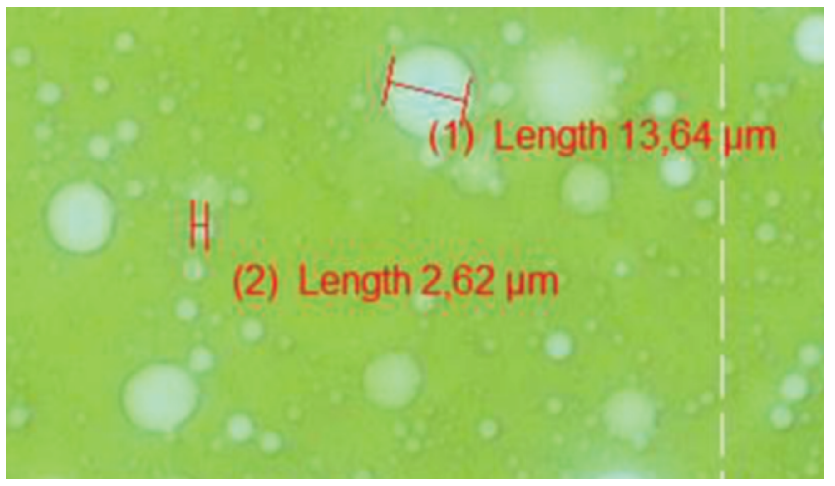

(b)

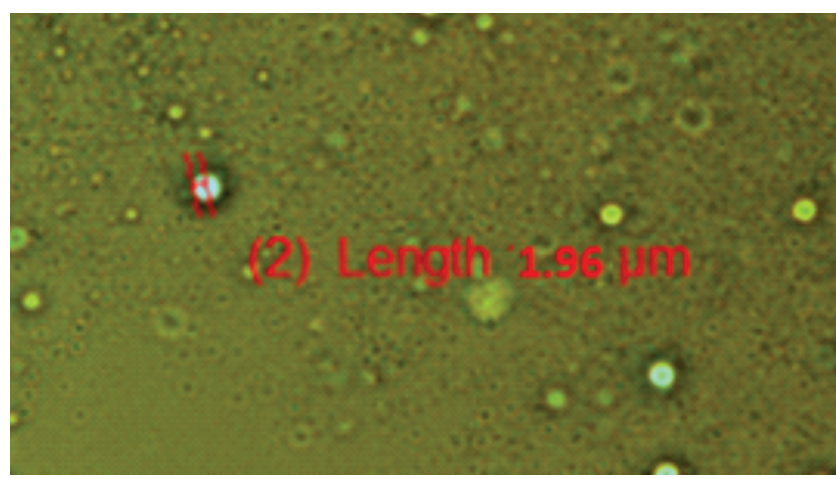

(c)

Figure 1. Microphotographs taken at ambient conditions of the water-in-oil emulsions prepared in the present study. (a) Fluid $C(\phi=0.24)$; (b) Fluid $\mathrm{E}$ $(\phi=0.23)$; (c) Fluid F $(\phi=0.26)$.

As observed, for each one of the analyzed fluids (see Figures $3 a, 3 b$ and $3 c$ ) when the water contents increase, the water drop sizes increase also, i.e, the water drop size is directly proportional to the water volumetric fraction. This result agrees with the behavior reported for atmospheric emulsions (Arhuoma, Dong, Yang \& Idem, 2009; Plasencia, Pettersen \& Nydal, 2013). On the other hand, in Figure $3 \mathrm{~d}$ a comparison of the results for three of the evaluated emulsions is shown, and it is evident that the biggest water drops correspond to Fluid E, while the smaller ones belong to Fluid F. Table 1 depicts that Fluid E has the smallest asphaltene content, while Fluid $\mathrm{F}$ has the biggest one. The aforementioned indicates that although Fluid $\mathrm{F}$ has the highest water content $(0.26)$ in relation to Fluid $\mathrm{C}(0.24)$ and Fluid $\mathrm{E}(0.23)$, the drop size of Fluid $\mathrm{F}$ is the smallest. This behavior is mainly due to the asphaltene content, which is inversely proportional to the drop size (Gafonova \& Yarranton, 2001).

For all prepared emulsions, the water content (volumetric fraction) was determined by using the "water by distillation" technique (ASTM D4006-11) and the results are shown in Table 3.

\section{Rheological Behavior}

Measurements of pressure drops for all fluids and emulsions were carried out at different shear rates (58, 86 and $115 \mathrm{~s}^{-1}$ ) and at pressures between 5.6 MPa and $24.2 \mathrm{MPa}$ by using a capillary viscometer. This pressure range guarantees measurements at single phase conditions (i.e., above the bubble pressure of the respective reservoir fluid studied). Hereafter, only the results at $24.2 \mathrm{MPa}$ are presented because the results for the other evaluated pressures were very similar in tendency. To the best of our knowledge, it is the first time that the rheology of emulsions is studied and reported at such high pressures; usually the pressures reported in the literature do not exceed $10 \mathrm{MPa}$. Rheological behavior was analyzed at $60^{\circ} \mathrm{C}$, a temperature in the range of typical temperatures found in wells of heavy and extra-heavy oils of reservoirs in Colombia. A this temperature, both the preparation of emulsions and their rheological study are more difficult than at higher temperatures.

Figures $4 \mathrm{a}, 4 \mathrm{~b}$ and $4 \mathrm{c}$ show pressure drops versus flow rates for each fluid and emulsion, a linear relationship is evident between these variables. The pressure drops strongly increase with the water content (at the same flow rate), which is an indication of the emulsified nature of the water. The pressure drops also show a high sensibility to the flow rate for increasing water contents. 


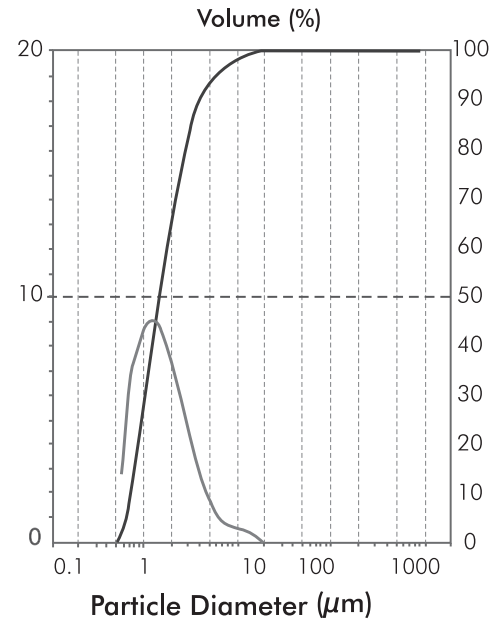

$\phi=0.11$

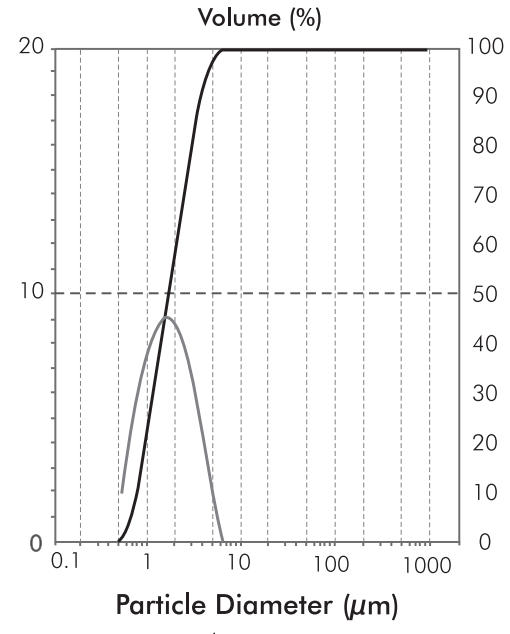

$\phi=0.16$

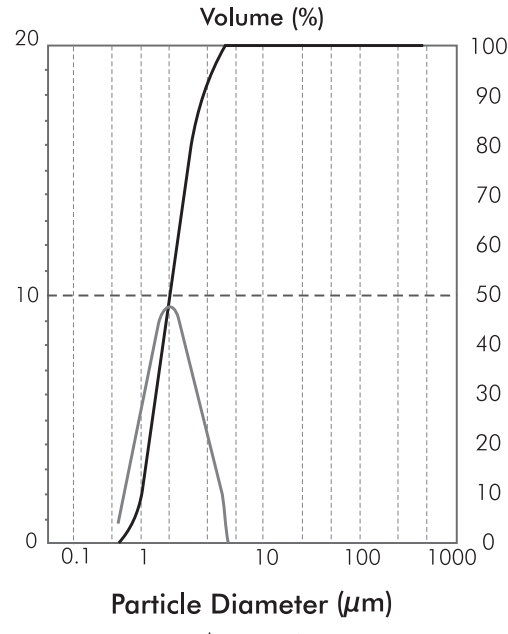

$\phi=0.24$

(a)

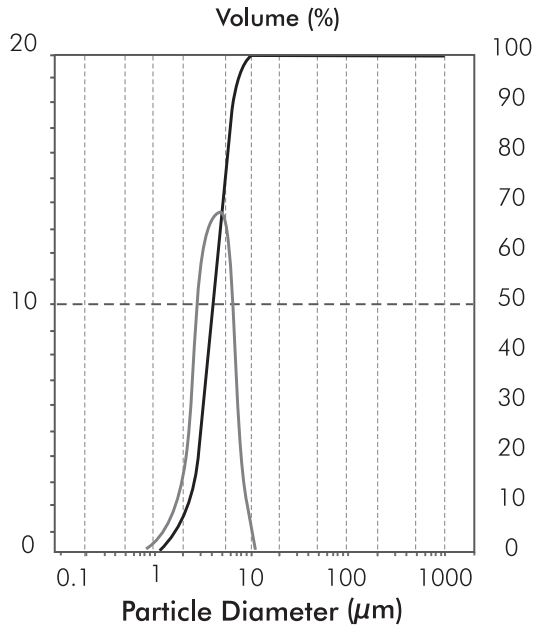

$\phi=0.11$

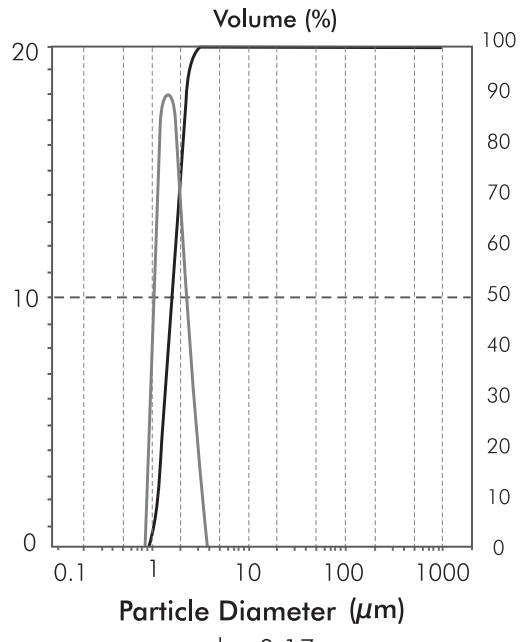

$\phi=0.17$

100
90
80
70
60
50
40
30
20
10
0

(b)

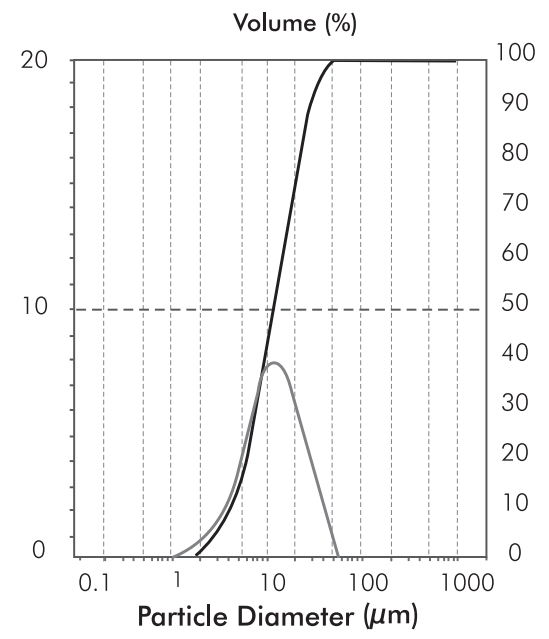

$\phi=0.23$

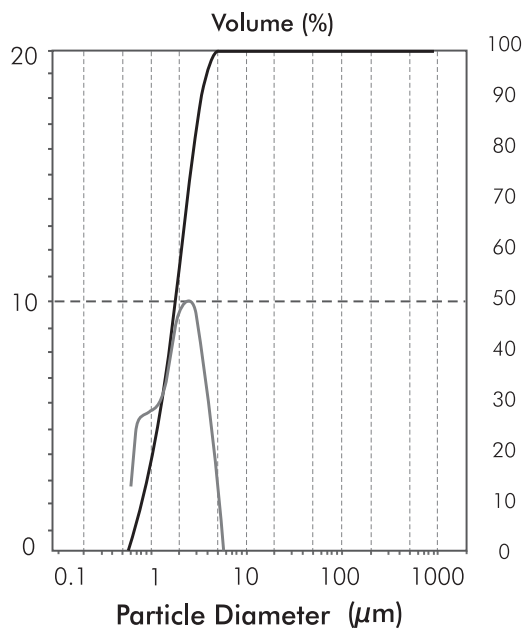

$\phi=0.26$

Figure 2. Frequency distribution and cumulative volume of drop size for the evaluated emulsions. (a) Fluid $C(\phi=0.11,0.16$ and 0.24$)$. (b) Fluid $E(\phi=0.11$ and 0.23$)$. (c) Fluid $F(\phi=0.17$ and 0.26$)$. 


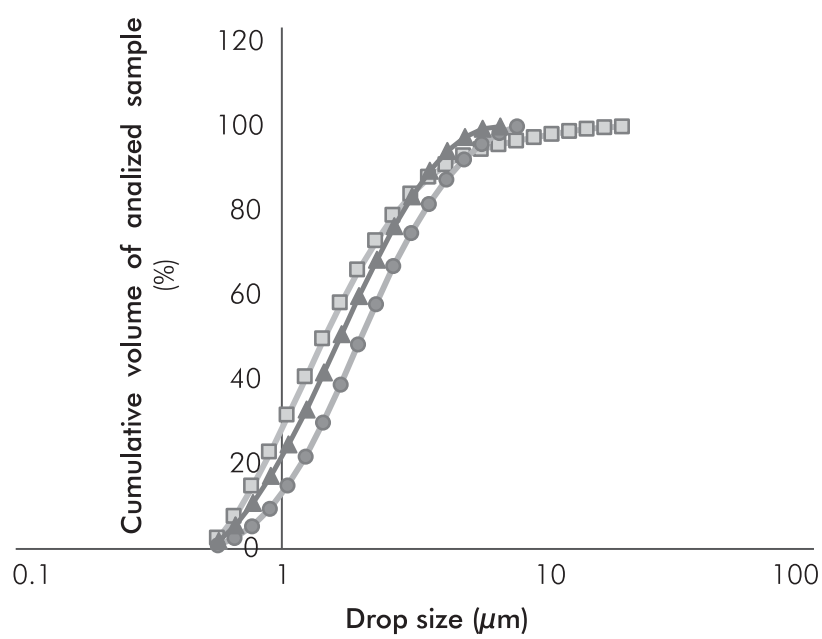

$\square \phi=0.11 \quad \Delta \phi=0.16 \quad \circ \phi=0.24$

(a)

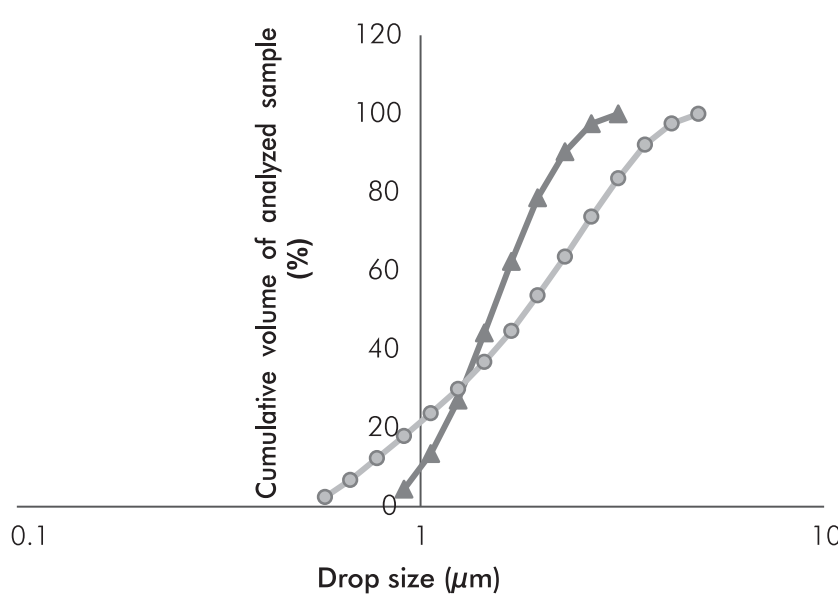

$\Delta \phi=0.17 \quad \circ \phi=0.26$

(c)

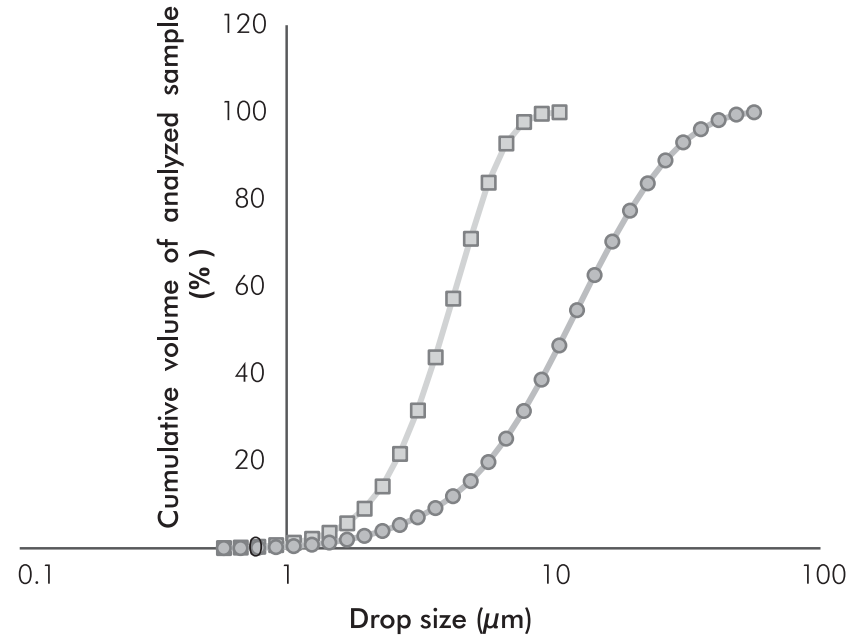

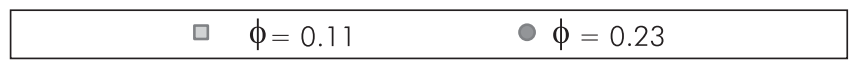

(b)

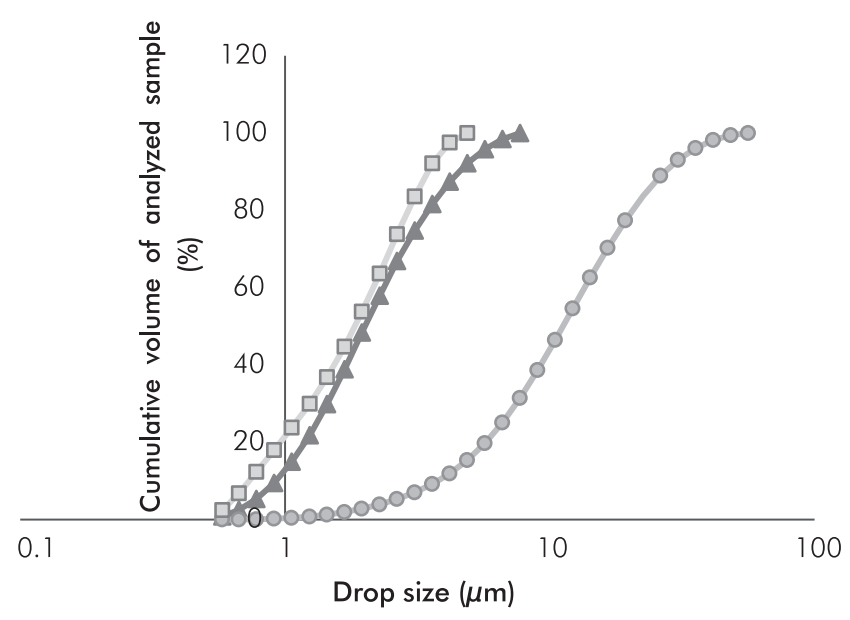

$\triangle$ Fluid $C \phi=0.24$

- Fluid $\mathrm{E} \phi=0.23$

$\square$ Fluid $\mathrm{F} \phi=0.26$

(d)

Figure 3. Drop size of the evaluated emulsions. (a) Fluid $C(\phi=0.11,0.16$ and 0.24$)$. (b) Fluid $E(\phi=0.11$ and 0.23$)$. (c) Fluid $F(\phi=0.17$ and 0.26). (d) Comparison between drop sizes.

Table 3. Summary of water volumetric fractions $(\phi)$ for the emulsions studied.

\begin{tabular}{|c|ccc|}
\hline \multirow{2}{*}{ Sample } & & Volume Fractions of Water $(\phi)$ & \\
& Fluid C & Fluid E & Fluid F \\
\hline Reference fluid & 0 & 0.02 & 0.02 \\
\hline Emulsion \# 1 & 0.11 & 0.11 & $*$ \\
\hline Emulsion \# 2 & 0.16 & $*$ & 0.17 \\
\hline Emulsion \# 3 & 0.24 & 0.23 & 0.26 \\
\hline
\end{tabular}

* Not used in the present work. 


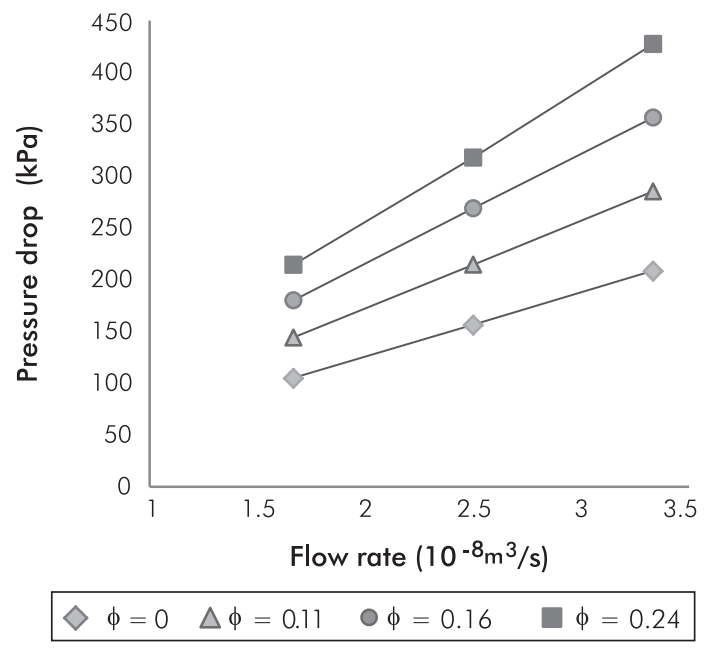

(a)

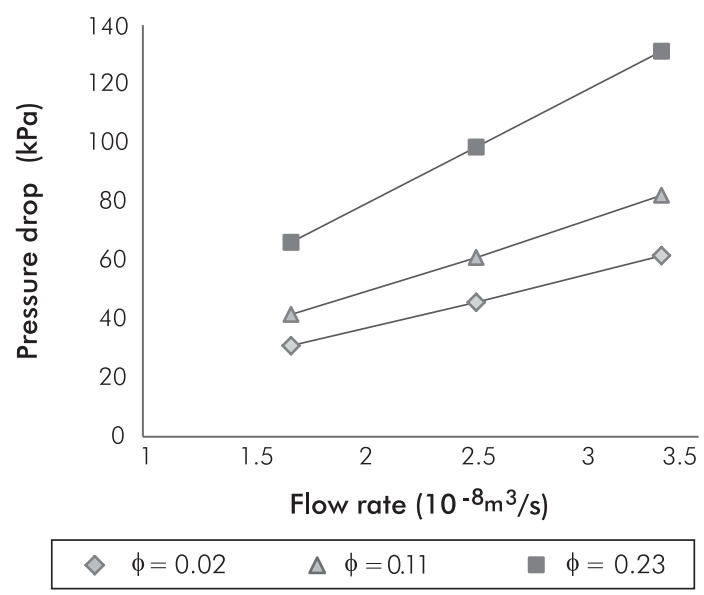

(b)

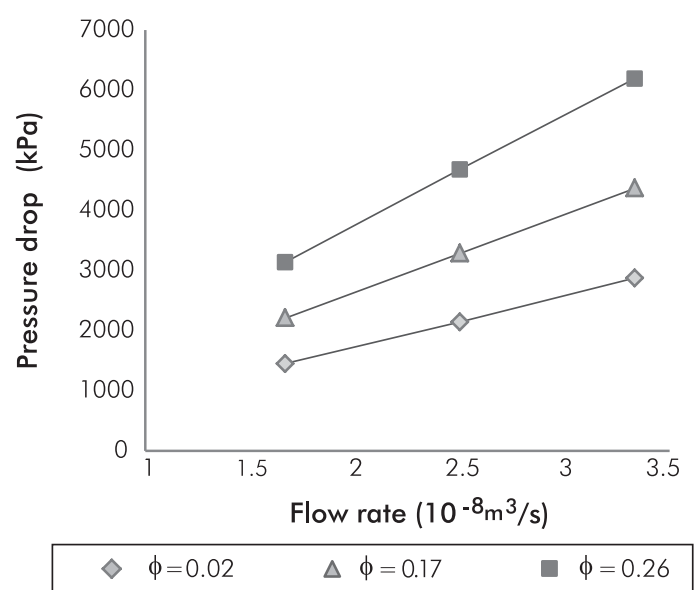

(c)

Figure 4. Profile of pressure drops at $24.2 \mathrm{MPa}$ and $60^{\circ} \mathrm{C}$. (a) Fluid $\mathrm{C}$ $(\phi=0,0.11,0.16$ and 0.24$) ;(b)$ Fluid $E(\phi=0.02,0.11$ and 0.23$) ;(c)$ Fluid $F(\phi=0.02,0.17$ and 0.26$)$.
Figures $5 \mathrm{a}, 5 \mathrm{~b}$ and $5 \mathrm{c}$ depict the relationship between shear stress and shear rate (at the wall). A linear relationship is evident between these variables, indicating that all fluids and emulsions exhibit a nearly Newtonian rheology within the complete range of pressures, shear rates, volumetric fractions, etc., used in this research.

Figures $6 \mathrm{a}, 6 \mathrm{~b}$ and $6 \mathrm{c}$ summarize the impact of both pressure and shear rate on the viscosity of all emulsions at different water contents. In this case, the viscosities noticeably increase with the water content (most of $100 \%$ between the limits of volume fraction). The results for the emulsified Fluids $\mathrm{C}$ and $\mathrm{E}$ (see Figures $6 \mathrm{a}$ and $6 \mathrm{~b}$ ) confirm that the Newtonian behavior inferred by the linear tendency of the shear stress versus the shear rate (see Figure 5) is not affected by changes in pressure at the temperature here used. The above mentioned can be reinforced by the fact that the highest viscosity standard deviation for these Fluids was $7 \times 10^{-4} \mathrm{~Pa} \cdot \mathrm{s}$ at the pressures and the shear rates studied. Newtonian behavior of live fluids has been observed by other authors (Alboudwarej et al., 2007); and rheological studies for different crude oil emulsions have concluded that many of these behave also like Newtonian fluids (Camy et al., 1975; Alvarado \& Marsden, 1979; Steinborn \& Flock, 1983; Wyslouzil, Kessick \& Masliyah, 1987). Obviously, at higher temperatures the Newtonian behavior would be stronger. On the other hand, in Figure $6 \mathrm{c}$ it can be observed that the emulsified Fluid F shows a very small variation in viscosity versus shear rate (the highest standard deviation at the evaluated pressures and shear rates was $0.05 \mathrm{~Pa} \cdot \mathrm{s}$ ), completely negligible for practical purposes. Again, this fluid has the highest asphaltene content. Table 4 shows the summary of the viscosities for all fluids and emulsions studied in the present research work using the capillary viscometer. It can be observed the above mentioned behavior in a quantitative way.

It is important to point out that in the present work, a Non-Newtonian behavior could have been manifested for water contents greater than 30\% (Omar, Desouky \& Karama, 1991); but these contents were not relevant in the present research because it focused on typical water cut levels of down-hole samples from petroleum reservoir or those which are feasible of obtaining by thermal dehydration. Changes in structural 
characteristics of a fluid due to variations in the flow (Non-Newtonian behavior) could be manifested also when the structure of the interfacial film formed at the

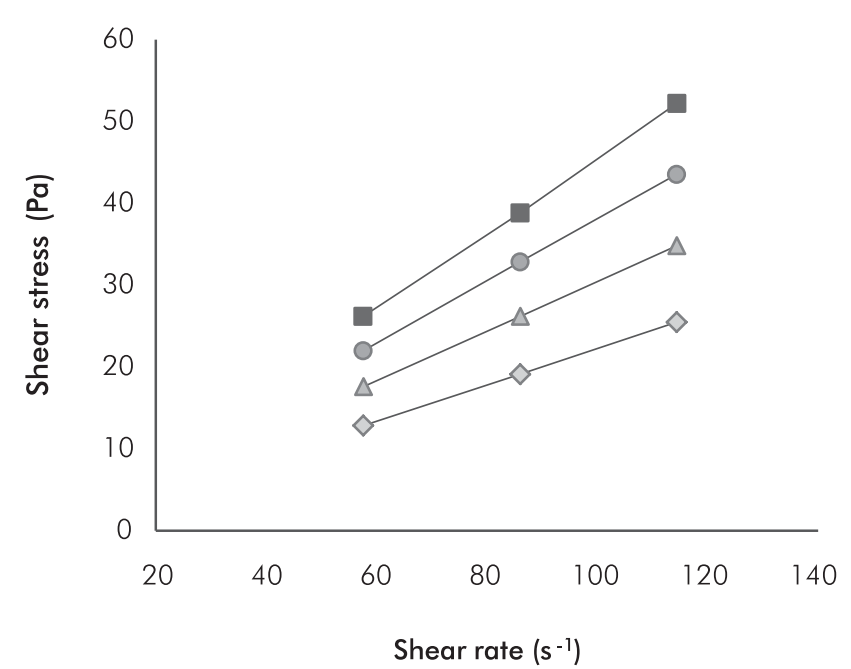

$\diamond \phi=0 \quad \Delta \phi=0.11 \quad \circ \phi=0.16 \quad \square=0.24$

(a)

a) interface is broken as the shear rate increases (Li et al., 2002). The above mentioned ratifies the stability of the emulsions evaluated in the present work.

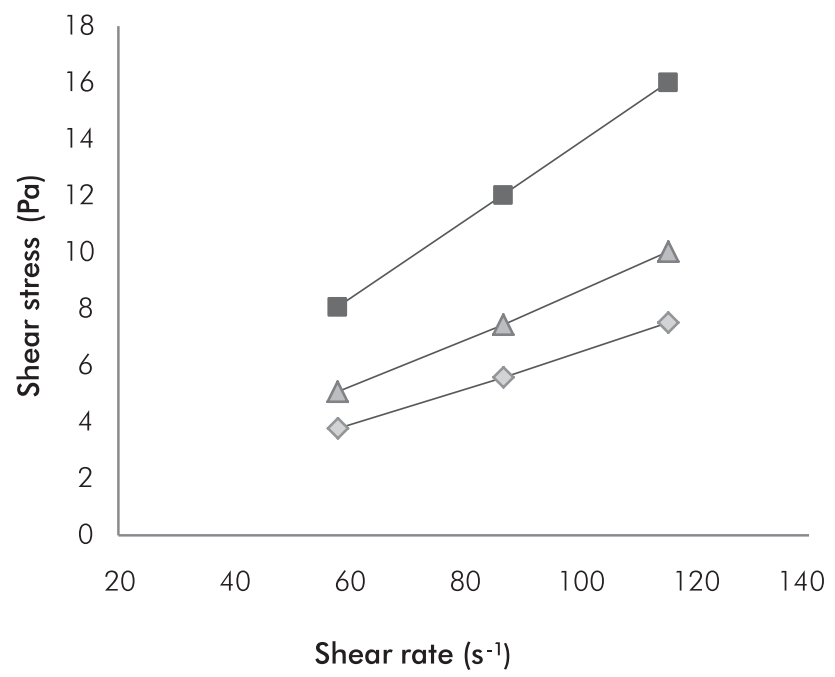

\begin{tabular}{|c|c|c|}
\hline$\diamond \phi=0.02$ & $\Delta \phi=0.11$ & $\phi=0.23$ \\
\hline
\end{tabular}

(b)

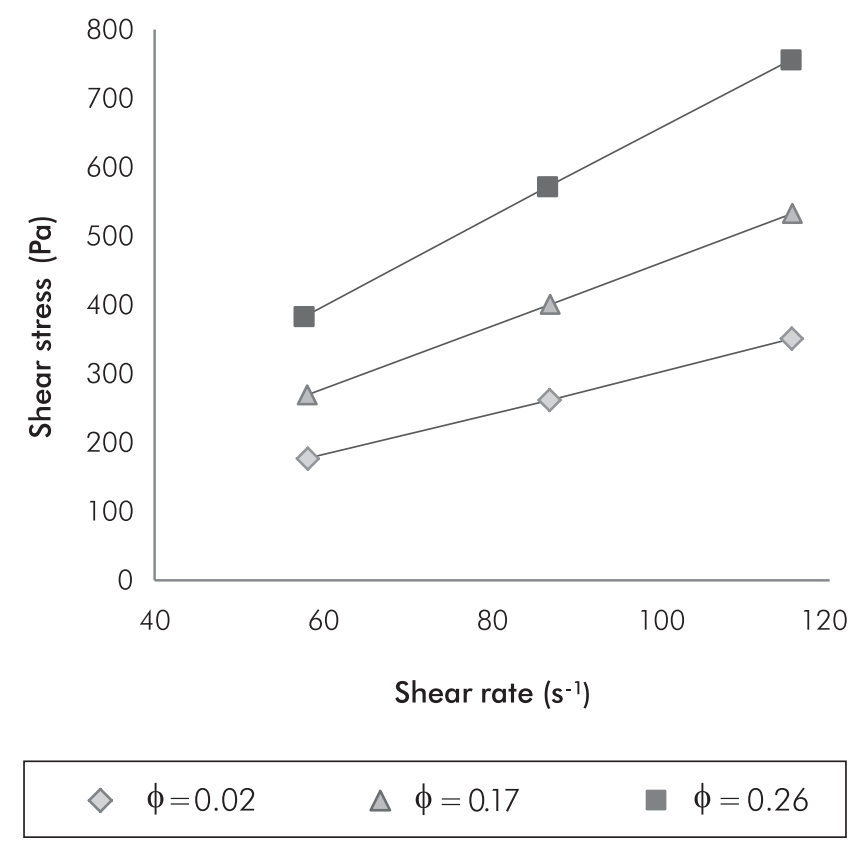

(c)

Figure 5. Flux curves at $24.2 \mathrm{MPa}$ and $60^{\circ} \mathrm{C}$ for the fluids evaluated. (a) Fluid $\mathrm{C}(\phi=0,0.11,0.16$ and 0.24$)$;

(b) Fluid $E(\phi=0.02,0.11$ and 0.23$)$. (c) Fluid $F(\phi=0.02,0.17$ and 0.26$)$. 

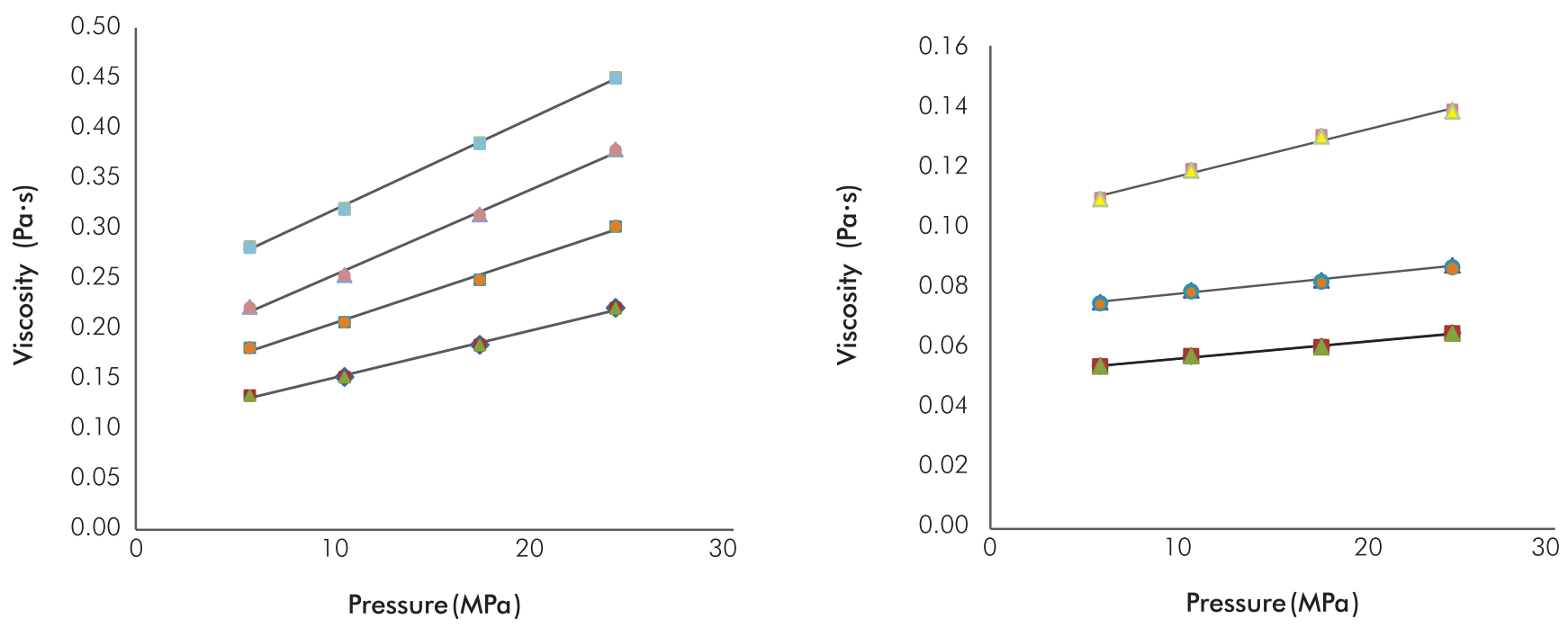

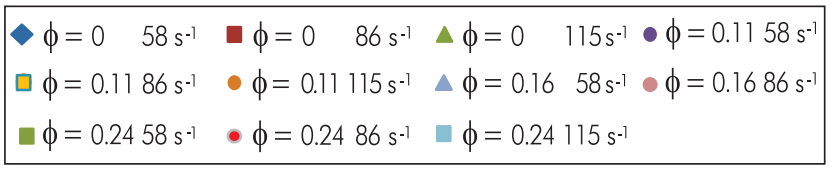

(a)

\begin{tabular}{|c|c|c|}
\hline$\phi=0.0258 \mathrm{~s}^{-1}$ & $\phi=0.0286 \mathrm{~s}^{-1}$ & $\Delta \phi=0.02115 \mathrm{~s}^{-1}$ \\
\hline$\Delta \phi=0.1158 \mathrm{~s}^{-1}$ & $\phi=0.1186 \mathrm{~s}^{-1}$ & $\phi=0.11115 \mathrm{~s}^{-1}$ \\
\hline$+\phi=0.2358 \mathrm{~s}^{-1}$ & $\phi=0.2386 \mathrm{~s}^{-1}$ & $\Delta \phi=0.23115 \mathrm{~s}^{-1}$ \\
\hline
\end{tabular}

(b)

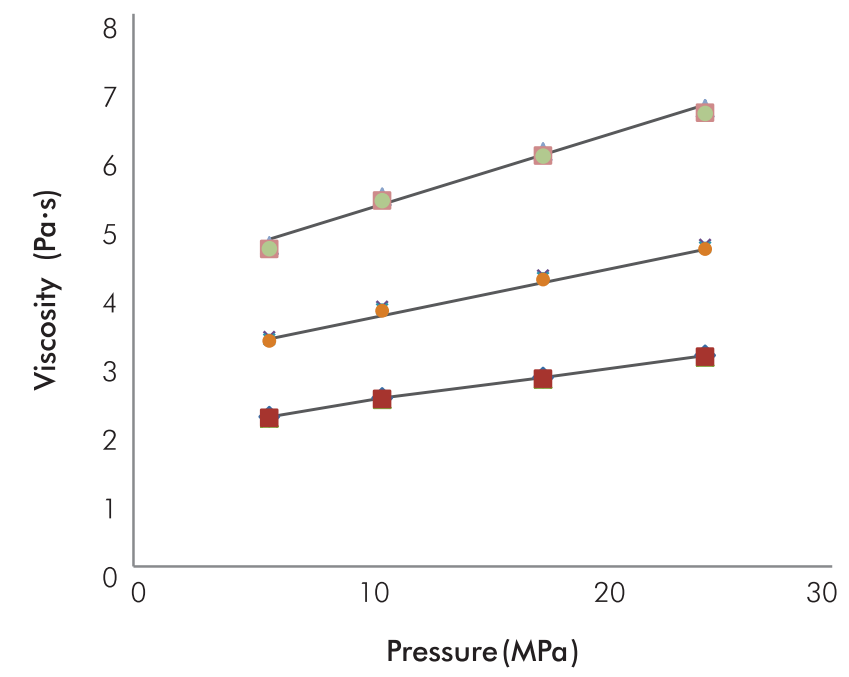

\begin{tabular}{|c|c|c|}
\hline$\phi=0.0258 \mathrm{~s}^{-1}$ & $\phi=0.0286 \mathrm{~s}^{-1}$ & $\Delta \phi=0.02115 \mathrm{~s}^{-1}$ \\
\hline$\times \phi=0.1758 \mathrm{~s}-1$ & $* \phi=0.1786 \mathrm{~s}-1$ & - $\phi=0.17115 \mathrm{~s}-1$ \\
\hline$\Delta \phi=0.2658 \mathrm{~s}^{-1}$ & $\phi=0.2686 \mathrm{~s}^{-1}$ & $\phi=0.26115 \mathrm{~s}^{-1}$ \\
\hline
\end{tabular}

(c)

Figure 6. Viscosity vs pressure and shear rate at $60^{\circ} \mathrm{C}$ for the fluids evaluated. (a) Fluid $\mathrm{C}(\phi=0,0.11,0.16$ and 0.24$)$;

(b) Fluid $\mathrm{E}(\phi=0.02,0.11$ and 0.23$)$; (c) Fluid $\mathrm{F}(\phi=0.02,0.17$ and 0.26$)$. 
RHEOLOGICAL BEHAVIOR OF WATER-IN-OIL EMULSIONS OF HEAVY AND EXTRA-HEAVY LIVE OILS: EXPERIMENTAL EVALUATION

Table 4. Summary of the viscosity at different pressures using capillary viscometer, shear rates and water cuts for Fluids C, E and F.

\begin{tabular}{|c|c|c|c|c|c|}
\hline \multirow{2}{*}{$\begin{array}{l}\text { Pressure } \\
\text { (MPa) }\end{array}$} & \multirow{2}{*}{ Fluid } & \multirow{2}{*}{$\begin{array}{c}\text { Volume } \\
\text { Fraction of Water }\end{array}$} & \multicolumn{3}{|c|}{ Viscosity $(\mathrm{Pa} \cdot \mathrm{s})$} \\
\hline & & & @ $58 \mathrm{~s}^{-1}$ & @ $86 \mathrm{~s}^{-1}$ & @ $115 \mathrm{~s}^{-1}$ \\
\hline \multirow{10}{*}{24.2} & C & 0.00 & 0.2209 & 0.2207 & 0.2205 \\
\hline & $C$ & 0.11 & 0.3025 & 0.3020 & 0.3017 \\
\hline & $C$ & 0.16 & 0.3786 & 0.3783 & 0.3781 \\
\hline & $\mathrm{C}$ & 0.24 & 0.4505 & 0.4499 & 0.4495 \\
\hline & $E$ & 0.02 & 0.0648 & 0.0647 & 0.0646 \\
\hline & $E$ & 0.11 & 0.0872 & 0.0866 & 0.0861 \\
\hline & $E$ & 0.23 & 0.1397 & 0.1388 & 0.1382 \\
\hline & $\mathrm{F}$ & 0.02 & 3.0549 & 3.0364 & 3.0234 \\
\hline & $\mathrm{F}$ & 0.17 & 4.6559 & 4.6203 & 4.5952 \\
\hline & $\mathrm{F}$ & 0.26 & 6.6287 & 6.5658 & 6.5216 \\
\hline \multirow{6}{*}{20.8} & $\mathrm{E}$ & 0.02 & 0.0604 & 0.0602 & 0.0601 \\
\hline & $E$ & 0.11 & 0.0823 & 0.0818 & 0.0815 \\
\hline & $E$ & 0.23 & 0.1312 & 0.1305 & 0.1300 \\
\hline & $\mathrm{F}$ & 0.02 & 2.7348 & 2.7176 & 2.7055 \\
\hline & $\mathrm{F}$ & 0.17 & 4.2121 & 4.1768 & 4.1520 \\
\hline & $\mathrm{F}$ & 0.26 & 6.0030 & 5.9450 & 5.9043 \\
\hline \multirow{10}{*}{17.3} & $C$ & 0.00 & 0.1842 & 0.1840 & 0.1839 \\
\hline & $\mathrm{C}$ & 0.11 & 0.2492 & 0.2489 & 0.2487 \\
\hline & $\mathrm{C}$ & 0.16 & 0.3138 & 0.3135 & 0.3133 \\
\hline & $\mathrm{C}$ & 0.24 & 0.3855 & 0.3847 & 0.3842 \\
\hline & $E$ & 0.02 & 0.0572 & 0.0572 & 0.0572 \\
\hline & $E$ & 0.11 & 0.0790 & 0.0786 & 0.0784 \\
\hline & $E$ & 0.23 & 0.1199 & 0.1192 & 0.1187 \\
\hline & $\mathrm{F}$ & 0.02 & 2.4392 & 2.4231 & 2.4117 \\
\hline & $\mathrm{F}$ & 0.17 & 3.7590 & 3.7247 & 3.7005 \\
\hline & $\mathrm{F}$ & 0.26 & 5.3476 & 5.2951 & 5.2581 \\
\hline \multirow{6}{*}{13.9} & $E$ & 0.02 & 0.0539 & 0.0538 & 0.0538 \\
\hline & $E$ & 0.11 & 0.0750 & 0.0747 & 0.0744 \\
\hline & $E$ & 0.23 & 0.1103 & 0.1096 & 0.1092 \\
\hline & $\mathrm{F}$ & 0.02 & 2.1666 & 2.1516 & 2.1409 \\
\hline & $\mathrm{F}$ & 0.17 & 3.3210 & 3.2880 & 3.2640 \\
\hline & $\mathrm{F}$ & 0.26 & 4.6411 & 4.5946 & 4.5620 \\
\hline \multirow{4}{*}{10.4} & $C$ & 0.00 & 0.1522 & 0.1520 & 0.1519 \\
\hline & $C$ & 0.11 & 0.2069 & 0.2067 & 0.2065 \\
\hline & $\mathrm{C}$ & 0.16 & 0.2535 & 0.2531 & 0.2529 \\
\hline & $C$ & 0.24 & 0.3204 & 0.3195 & 0.3189 \\
\hline \multirow{4}{*}{5.6} & $C$ & 0.00 & $*$ & 0.1336 & 0.1336 \\
\hline & $C$ & 0.11 & 0.1813 & 0.1811 & 0.1810 \\
\hline & $C$ & 0.16 & 0.2219 & 0.2213 & 0.2208 \\
\hline & $C$ & 0.24 & 0.2821 & 0.2814 & 0.2808 \\
\hline
\end{tabular}

* Not measured in the present work. 


\section{ANALYSIS OF RESULTS}

The analysis of viscosity versus pressure and the volume fraction of water for the live emulsions are graphically presented. As is a well-known fact -both theoretically and experimentally- for emulsions prepared from dead oils the viscosity versus water volumetric content exhibits an exponential trend (Broughton \& Squires, 1938; Mooney, 1951; Ronningsen, 1995; Al-Roomi, George, Elgibaly \& Elkamel, 2004; Azodi \& Nazar, 2013). However, and in contrast, experimental studies and models of viscosity versus water content for emulsions from live oils are very scarce (Johnsen \& Rønningsen, 2003; Alboudwarej et al., 2007). Figure 7 then shows, at different pressures and for all the live emulsions prepared in the present study, the semi-log plot of the viscosity against volume fraction of water. As observed, this Figure reveals that for Fluids C

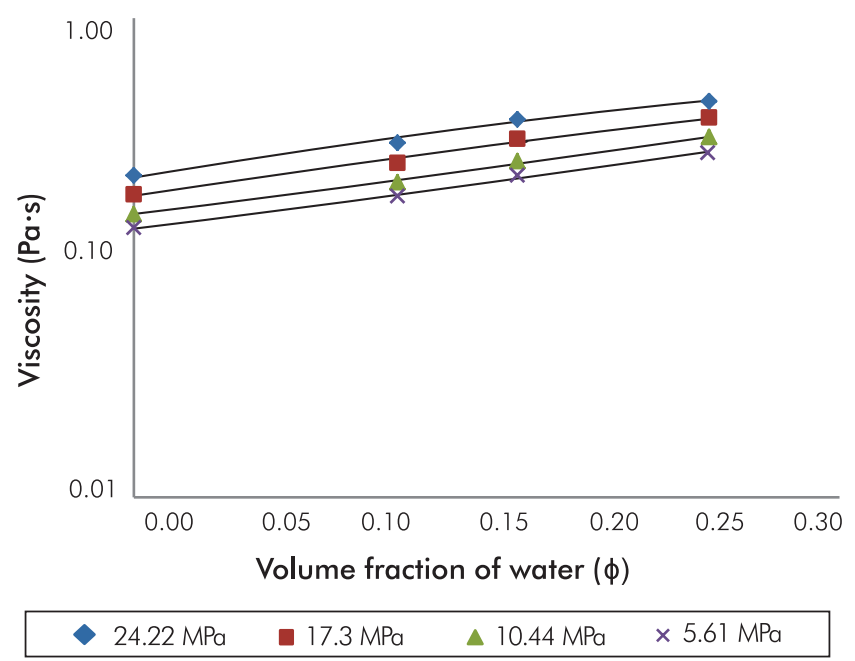

(a) and $\mathrm{E}$ the behavior is linear, while Fluid $\mathrm{F}$ has a slightly non-linear trend. However, the exponential behavior of the viscosity for all the studied emulsions is evident. A possible explanation for the non-linear trend of Fluid $\mathrm{F}$ is that the viscosity varied as a function of pressure: Since the pressure drops suffered by the fluid in the capillary were so high, it generated the change on the average pressure and an effect on apparent viscosity. This could not be avoided because the design of the viscometer not allow the use of a shorter capillary, or the use of a capillary tube with a larger diameter.

Figure 8 has a similar purpose, but here the pressure, instead of the volume fraction of water, is used in the $\mathrm{x}$-axes. The logarithmic trend is perfectly accomplished for all the live emulsions, including those of Fluid $\mathrm{F}$, in accordance with other authors (Alboudwarej et al., 2007).

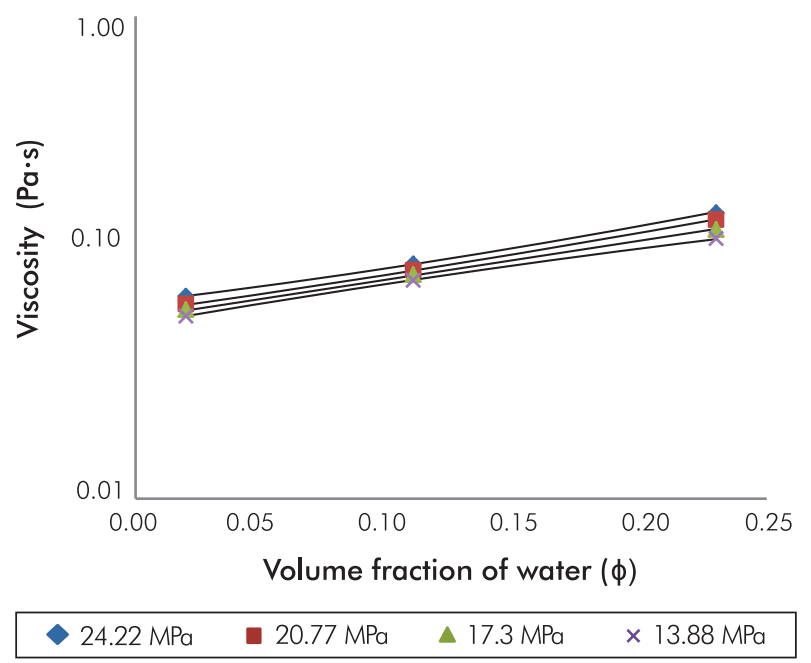

(b)

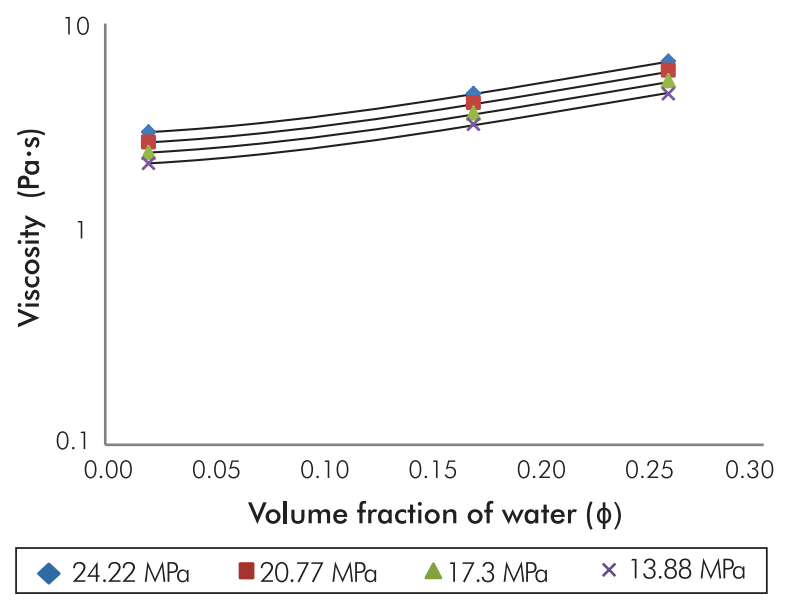

(c)

Figure 7. Semi-log plot of the viscosity vs volume fraction of water for the fluids evaluated at $60^{\circ} \mathrm{C}$. (a) Fluid $\mathrm{C}(\phi=0,0.11,0.16$ and 0.24$)$. (b) Fluid $\mathrm{E}(\phi=0.02,0.11$ and 0.23$)$. (c) Fluid $\mathrm{F}(\phi=0.02,0.17$ and 0.26$)$. 


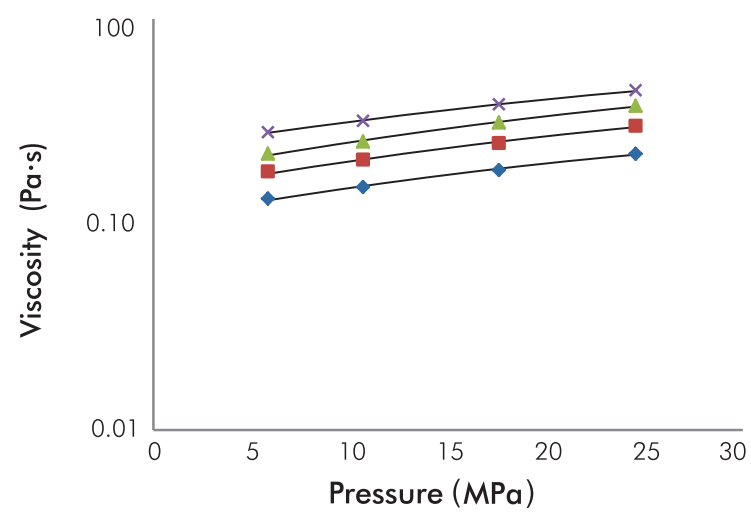

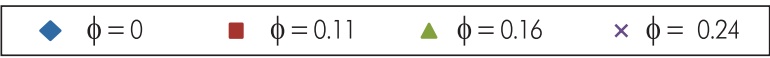

(a)

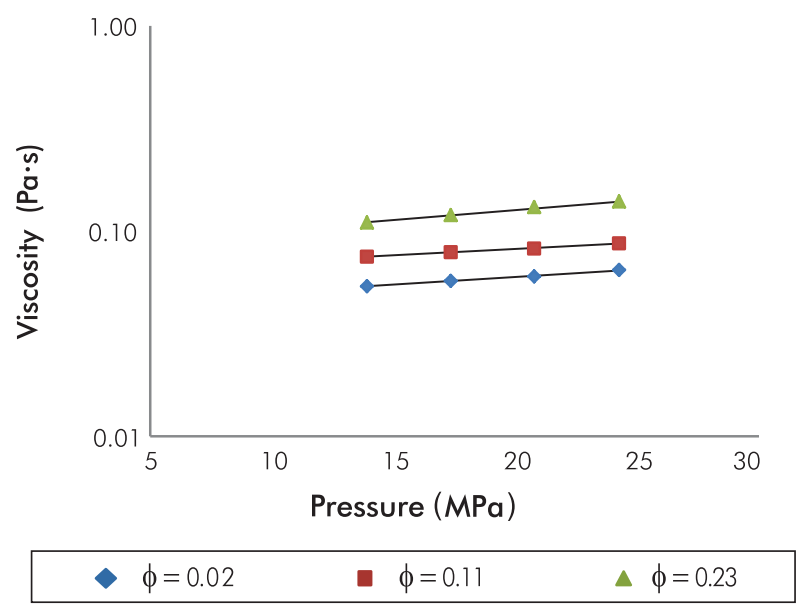

(b)

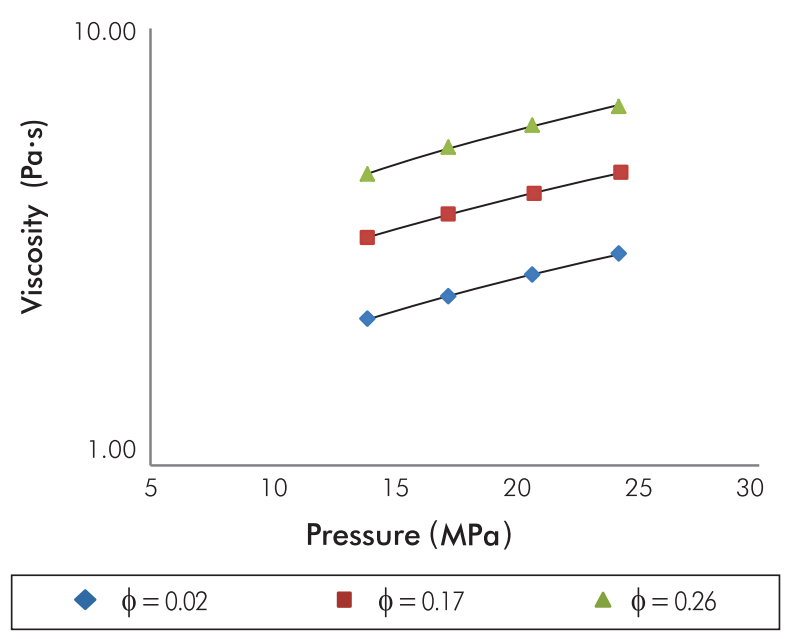

(c)

Figure 8. Semi-log plot of the viscosity vs pressure for the fluids evaluated at $60^{\circ} \mathrm{C}$. (a) Fluid $\mathrm{C}(\phi=0,0.11,0.16$ and 0.24$)$. (b) Fluid $\mathrm{E}(\phi=0.02$, 0.11 and 0.23$)$. (c) Fluid $F(\phi=0.02,0.17$ and 0.26$)$.

\section{CONCLUSIONS}

- Pressure drops increase visibly with the emulsified water content. Consequently, the shear stress also increases noticeably with the water volume fraction $(\phi)$. Within the pressure range here evaluated, and whose upper limit was $24 \mathrm{MPa}$, the behavior of the shear stress against shear rate is linear. Therefore, for the evaluated fluids and emulsions, the structural characteristics are not visibly influenced by neither the flow nor the pressure; and they can be considered as Newtonian fluids at the temperature, shear rates and water cuts here used. Obviously, at higher temperatures, the Newtonian behavior is stronger and vice versa. At higher water contents, wider shear rate ranges, low temperatures, particularly for the Fluid F, a Non-Newtonian behavior could be expected. For practical purposes, the viscosity of these live emulsions follows a mathematical exponential behavior with respect to the water volume fraction, which is similar to the tendency observed in dead oils at atmospheric pressure.

\section{ACKNOWLEDGEMENTS}

The authors wish to thank Ecopetrol S.A. - Instituto Colombiano del Petróleo (ICP) for allowing the use of equipment and information to carry out the present work. The reviewers' contributions are also highly valued.

\section{REFERENCES}

Abivin, P., Henaut, C., Chaudemanche, C., Argillier, J. F., Chinesta, F. \& Moan, M. (2009). Dispersed systems in heavy crude oil. Oil Gas Sci. Technol., 64(5), 557-570.

Albers, W. \& Overbeek, J. T. G. (1960). Stability of emulsions of water in oil III. Flocculation and redispersion of water droplets covered by amphipolar monolayers. J. Colloid Sci., 15(6), 489-502.

Alboudwarej, H., Muhammad, M., Shahraki, A., Dubey, S., Vreenegoor, L. \& Saleh, J. (2007). Rheology of heavy-oil emulsions. SPE Prod. Oper., 22(3), 285-293. 
Al-Roomi, Y., George, R., Elgibaly, A. \& Elkamel, A. (2004). Use of a novel surfactant for improving the transportability/transportation of heavy/viscous crude oils. J. Petrol. Sci. Eng., 42(2), 235-243.

Alvarado, D. \& Marsden, S. S. (1979). Flow of oil-in-water emulsions through tubes and porous media. SPE J., 19(6), 369-377.

André, A. L. B. (2009). Investigation of the stability and separation of water-in-oil emulsion. Doctoral Dissertation, Department of Process Engineering. Stellenbosch University, Stellenbosch, 124pp.

Arhuoma, M., Dong, M., Yang, D. \& Idem, R. (2009). Determination of water-in-oil emulsion viscosity in porous media. Ind. Eng. Chem. Res., 48(15), 7092-7102.

ASTM Standard D5307-97. Test Method for Determination of Boiling Range Distribution of Crude Petroleum by Gas Chromatography. Annual Book of Standards, ASTM International, West Conshohocken, PA, 2007.

ASTM Standard D4006-11. Test Method for Water in Crude Oil by Distillation. Annual Book of Standards, ASTM International, West Conshohocken, PA, 2012.

Azodi, M. \& Nazar, A. R. S. (2013). Experimental design approach to investigate the effects of operating factors on the surface tension, viscosity, and stability of heavy crude oil-in-water emulsions. J. Disp. Sci. Technol., 34(2), 273-282.

Barrufet, M. A. \& Setiadarma, A. (2003). Experimental viscosities of heavy oil mixtures up to $450 \mathrm{~K}$ and high pressures using a mercury capillary viscometer. J. Petrol. Sci. Eng., 40(1), 17-26.

Binks, B. P., Clint, J. H., Fletcher, P. D. I., Rippon, S., Lubetkin, S. D. \& Mulqueen, P. J. (1999). Kinetics of swelling of oil-in-water emulsions stabilized by different surfactants. Langmuir, 15(13), 4495-4501.

Broughton, G. \& Squires, L. (1938). The viscosity of oil-water emulsions. J. Phys. Chem., 42(2), 253-263.

Camy, J. P., Marsden, S. S., Hung-B., J. E., Arihara, N., Casse, F. J., Alvarado-Q., D. A., Mandel, L., Mobarak, S., Gonzalez-G. H. O., Mao, M. L., Samaniego-V., F., Romero-G., E., Rivera-R., J. \& Marius, C. G. (1975). The rheology of crude oil dispersions. SPE Oilfield Chemistry Symposium. Texas, USA. SPE-5299-MS.
David, A. \& Marsden Jr, S. S. (1969). The rheology of foam. Fall Meeting of the Society of Petroleum Engineers of AIME. Colorado, USA. SPE-2544-MS.

Forgiarini, A., Esquena, J., González, C. \& Solans, C. (2000). Studies of the relation between phase behavior and emulsification methods with nanoemulsion formation. Progr. Colloid Polym. Sci., 115: 36-39.

Gafonova, O. V. \& Yarranton, H. W. (2001). The stabilization of water-in-hydrocarbon emulsions by asphaltenes and resins. J. Colloid Int. Sci., 241(2), 469-478.

GPA 2286-95. Tentative Method of Extended Analysis for Natural Gas and Similar Gaseous Mixtures by Temperature Programmed Gas Chromatography. Gas Processors Association. 1995.

Haney, M. A. (1985). The differential viscometer. II. On-line viscosity detector for size-exclusion chromatography. $J$. Appl. Polym. Sci., 30(7), 3037-3049.

IP Test Methods 143. Determination of asphaltenes (heptane insolubles) in crude petroleum and petroleum products. 2004.

Johnsen, E. E. \& Rønningsen, H. P. (2003). Viscosity of 'live' water-in-crude-oil emulsions: experimental work and validation of correlations. J. Petrol. Sci. Eng., 38 (1-2), 23-36.

Katz, D. L. \& Firoozabadi, A. (1978). Predicting phase behavior of condensate/crude-oil systems using methane interaction coefficients. J. Petrol. Technol., 30(11), 1649-1655.

Kobayashi, H., Yoshida, K. \& Kurano, Y. (1991). A capillary viscometer with a bellows. Jpn. J. Appl. Phys., 30(6), 1331-1332.

Kokal, S. \& Álvarez, C. (2003). Reducing pressure drop in offshore pipelines by controlling the viscosities of pressurized emulsions. Middle East Oil Show. Bahrain. SPE-81511-MS.

Langevin, D., Poteau, S., Hénaut, I. \& Argillier, J. F. (2004). Crude oil emulsion properties and their application to heavy oil transportation. Oil Gas Sci. Technol., 59(5), 511-521.

Lethuaut, L., Métro, F. \& Genot, C. (2002). Effect of droplet size on lipid oxidation rates of oil-in-water emulsions stabilized by protein. JAOCS, 79(5), 425-430. 
Li, M., Xu, M., Ma, Y., Wu, Z. \& Christy, A. A. (2002). Interfacial film properties of asphaltenes and resins. Fuel, 81(14), 1847-1853.

Liauh, W. W. \& Liu, T. W. (1984). A capillary viscometer for the study of EOR polymers. SPE Enhanced Oil Recovery Symposium. Tulsa. SPE-12649-MS.

Malkin, A. Y., Masalova, I., Slatter, P. \& Wilson, K. (2004). Effect of droplet size on the rheological properties of highly-concentrated w/o emulsions. Rheol. Acta, 43(6), 584-591.

Martín-Alfonso, M. J., Martínez-Boza, F. J., Navarro, F. J., Fernández, M. \& Gallegos, C. (2007). Pressuretemperature-viscosity relationship for heavy petroleum fractions. Fuel, 86(1-2), 227-233.

Mason, T. G., Bibette, J. \& Weitz, D. A. (1996). Yielding and flow of monodisperse emulsions. J. Colloid Int. Sci., 179(2), 439-448.

Memon, A., Gao, J., Taylor, S., Engel, T. \& Jia, N. (2010). A systematic workflow process for heavy oil characterization: Experimental techniques and challenges. Canadian Unconventional Resources and International Petroleum Conference. Calgary. SPE-137006-MS

Mooney, M. (1951). The viscosity of a concentrated suspension of spherical particles. J. Colloid Sci., 6(2), 162-170.

Moradi, M., Alvarado, V. \& Huzurbazar, S. (2010). Effect of salinity on water-in-crude oil emulsion: evaluation through drop-size distribution proxy. Energy Fuels, 25(1), 260-268.

Muller, R., Lessnig, W., Platz, S. \& Koepke, G. (1966). U.S. Patent No. 3,283,565A. Industrial capillary viscometer. Washington.

Munoz, J. C. \& Yeow, Y. L. (1996). Applications of maximum entropy method in capillary viscometry. Rheol. Acta, 35(1), 76-82.

Nagarajan, N. R., Honarpour, M. M. \& Sampath, K. (2007). Reservoir-fluid sampling and characterization key to efficient reservoir management. J. Petrol. Technol., 59(8), 80-91.

Omar, A. E., Desouky, S. M. \& Karama, B. (1991). Rheological characteristics of Saudi crude oil emulsions. J. Petrol. Sci. Eng., 6(2), 149-160.
Pal, R. (2000). Shear viscosity behavior of emulsions of two immiscible liquids. J. Colloid Int. Sci., 225(2), 359-366.

Pal, R. \& Rhodes, E. (1985). A novel viscosity correlation for non-Newtonian concentrated emulsions. J. Colloid Int. Sci., 107(2), 301-307.

Pal, R. \& Rhodes, E. (1989). Viscosity/concentration relationships for emulsions. J. Rheol., 33: 1021-1045.

Pays, K., Giermanska-Kahn, J., Pouligny, B., Bibette, J. \& Leal-Calderon, F. (2002). Double emulsions: how does release occur?. J. Control. Release, 79(1-3), 193-205.

Plasencia, J., Pettersen, B. \& Nydal, O. J. (2013). Pipe flow of water-in-crude oil emulsions: Effective viscosity, inversion point and droplet size distribution. J. Petrol. Sci. Eng., 101: 35-43.

Princen, H. M., Aronson, M. P. \& Moser, J. C. (1980). Highly concentrated emulsions. II. Real systems. The effect of film thickness and contact angle on the volume fraction in creamed emulsions. J. Colloid Int. Sci., 75(1), 246-270.

Ronningsen, H. (1995). Correlations for predicting viscosity of W/O-emulsions based on North Sea crude oils. SPE International Symposium on Oilfield Chemistry. Texas, SPE-28968-MS.

Steinborn, R. \& Flock, D. (1983). The rheology of heavy crude oils and their emulsions. J. Can. Pet. Technol., 22(5), 38-52.

Thompson, M. J., Pearson, J. R. A. \& Mackley, M. R. (2001). The effect of droplet extension on the rheology of emulsions of water in alkyd resin. J. Rheol., 45(6), 1341-1358.

Webster, J. G. \& Eren, H. (2014). Measurement, Instrumentation, and Sensors Handbook: Spatial, Mechanical, Thermal and Radiation Measurement. Boca Raton: CRC press, Taylor \& Francis Group.

Wenzel, H. G., Stelson, T. E. \& Brungraber, R. J. (1967). Flow of high expansion foam in pipes. J. Eng. Mech. Proc. of ASCE, 6: 153-165.

Wyslouzil, B. E., Kessick, M. A. \& Masliyah, J. H. (1987). Pipeline flow behaviour of heavy crude oil emulsions. CJChE, 65(3), 353-360. 


\section{AUTHORS}

\section{Libia Sofía Sandoval Rodríguez}

Affiliation: Universidad Industrial de Santander

Chemical Engineer, Universidad Industrial de Santander

M. Sc. in Chemical Engineering, Universidad Industrial de Santander

e-mail: libiasofia@gmail.com

\section{Wilson A. Cañas Marín}

Affiliation: Ecopetrol S. A.

Chemical Engineer, Universidad de Antioquia

M. Sc. in Chemical Engineering, Universidad Industrial de Santander

e-mail: wilson.cmarin@ecopetrol.com.co

\section{Ramiro Martínez Rey}

Affiliation: Universidad Industrial de Santander

Chemical Engineer, Universidad Industrial de Santander

M. Sc. in Chemical Engineering, University of Delaware

$\mathrm{Ph}$. D. in Chemical Engineering, University of Delaware

e-mail: rmartine@uis.edu.co

\section{NOTATION}

$\tau_{w} \quad$ Shear stress, $\mathrm{Pa}$

$\Delta P \quad$ Pressure drop through the capillary viscometer, $\mathrm{Pa}$

$L \quad$ Length of the capillary coil, $\mathrm{m}$

$\dot{\gamma}_{w} \quad$ Shear rate at the wall, $\mathrm{s}^{-1}$

$n \quad$ Slope of the measured $\log \left(\tau_{w}\right)-\log \left(\dot{\gamma}_{w}\right)$ curve

$Q \quad$ Flow rate, $\mathrm{m}^{3} / \mathrm{s}$

$D \quad$ Diameter of the capillary coil, $\mathrm{M}$

$\eta \quad$ Viscosity, $\mathrm{Pa} \cdot \mathrm{s}$ 